Volume: 12 Issue: 1 Year:2015

\title{
Revised version of physical education teachers' self-efficacy scale
}

\author{
İrfan Yildırım ${ }^{1}$
}

\begin{abstract}
The aim of the study is to revised the validity and reliability of physical education teachers' selfefficacy scale. Sample group of the study was consisted of 567 physical education teachers who is working in different geographic regions of Turkiye. In the study it was performed that explanatory factor analysis and confirmatory factor analysis for determinin the subscales and construct validity. As the result of the analyses; 33 items whose factor loading values were over 0.57 were clustered under nine factors whose eigenvalues were greater than 1 . It was found out that the percentage of variance explained by the nine factors was 78.362. When Cronbach Alpha internal consistency tests of the factors were analyzed, it was seen that $\alpha$ values of all factors were greater than 0.83 . As a result; it is predicted that the scale can be used in a valid and reliable way in order to measure self-efficacy of the physical education teachers.
\end{abstract}

Key words: Physical education; Reliability; Self-efficacy; Teacher; Validity

\section{Introduction}

Teachers, constituting the human capital of and serving in the educational system, are indispensible components of the system and they change and develop student behavior positively and educate human power to serve for the society. Today when more quality and competence is required; a modern teacher should not only be a person who teaches and assesses the students but also be a good leader, observer, manager and guide who organizes teaching-learning process. Teachers' performing educational competences required by the teaching profession relates to getting a good education as well as to their beliefs in performing their tasks and responsibilities. Hence the studies conducted indicate that people's beliefs affect their motivational levels, emotional status and behaviors. It is emphasized that one's belief in his competence affects and directs the way in which the behavior in question is done in terms of finalizing a behavior successfully (Bandura, 1977; 1997; Enochs and Riggs, 1990; Gökçe, 2000).

\footnotetext{
${ }^{1}$ Assist. Prof, Afyon Kocatepe University, School of Physical Education and Sports, Irfan.yildirim@aku.edu.tr
} 
Yıldırım İ. (2015). Revised version of physical education teachers' self-efficacy scale. International Journal of Human Sciences, 12(1), 870-886. doi: $10.14687 /$ ijhs.v12i1.3100

Self-efficacy, defined as one's belief in his/her own ability to complete tasks and reach goals successfully by organizing the necessary activities in order to realize a performance, is based on our belief in our abilities and is necessary to organize certain behaviors in order to attain and fulfill certain goals (Schmitz and Schwarzer, 2000). Self-efficacy is not a function produced by the abilities of the individuals but all of the judgments about what can be done through their abilities (Gürcan, 2005; Kiremit, 2006). Self-efficacy beliefs affect one's thinking styles, problem-solving skills and emotional reactions. People with low self-efficacy think that things are more difficult than they are and their problem-solving skills are very limited. People with high self-efficacy are more confident and their problem-solving skills and determination are higher (Enochs and Riggs, 1990; Pajares, 1997). Bandura (1986; 1997) argues that there are four starting points from which people develop their self-efficacy: mastery experience, vicarious experience, physiological and emotional stimulation and social influence.

Mastery experience includes experiences related to successes or failures; physiological and emotional stimulation include individual's psychologically or physically feeling good; vicarious experience includes one's increased beliefs in himself/herself by modeling others and observing their life styles and social influence includes being motivated by other people's encouraging words. On the other hand; self-efficacy requires four processes: cognitive process, motivational process, affective process and selection process. These processes play a key role in perceiving efficacy and they can prevent the desired behaviors from being realized or encourage them to be born (Bandura, 1986; 1994; 1997; Sckunk and Pajares, 2001; Bozgeyikli, 2005).

It is reported that self-efficacy beliefs can be used to explain individual differences in teaching activities and can make contributions to understand and to improve teacher behaviors (Enochs and Riggs, 1990; Pajares, 1997). Teachers' self-efficacy perceptions are their beliefs that they can successfully fulfill teaching function (Guskey and Passaro, 1994; Atıc1, 2000).

Teachers' self-efficacy perceptions are factors in their teaching activities and adoption to the education process (Pajares, 1997). When the self-efficacy concept is examined in terms of physical education teachers; we can describe the self-efficacy concept as teachers' beliefs that they can actively fulfill teaching function under all kind of negative and positive conditions and can make positive contributions to learning performance of the students (Yildirım, 2012a). The studies conducted suggest that self-efficacy perception of a teacher affects teaching and learning; particularly, teachers' practices in the classroom. Depending on the self-efficacy beliefs; teachers say that their efforts spent for teaching, educational objectives and amount of teaching-desire change. It is argued that there is positive correlation between teachers' positive self-efficacy 
Yildırım İ. (2015). Revised version of physical education teachers' self-efficacy scale. International Journal of Human Sciences, 12(1), 870-886. doi: $10.14687 /$ ijhs.v12i1.3100

perceptions and student success, student motivation and student competence and it is believed that teachers' self-efficacy perceptions are one of the most important factors that predict teacher competence (Tschannen-Moran et al. 1998; Schmitz and Schwarzer 2000; Tschannen-Moran and Woolfolk Hoy, 2001).

When the studies on teachers' self-efficacy are examined; it is seen that the studies on teachers' self-efficacy -designed and conducted in foreign languages by Akkoyunlu et al. (2005), Ekici (2005) and B1kmaz (2002)- are adaptation studies and scale development studies. On the other hand; although the studies conducted have focused on discovering teachers' general beliefs in self-efficacy, their beliefs in self-efficacy in relation with the academic branches have recently been investigated, too (Riggs and Enochs, 1990; Savran and Çakıroğlu, 2003; Gökyer, 2012). In this self-efficacy has been the subject of physical education teachers' has been the subject of the, some studies (Ünlü et al., 2008; Koparan et al. 2011, Yılmaz et al. 2010; Yıldırım 2012a, Yıldırım 2012b, Yildırım 2013).

\section{Purpose of the research}

In the literature it was seen that some scale for measuring the self-efficacy of physical teachers, but in order to determine the self-efficacy of physical education teacher needs to valid and reliable scale, also needs more contemporary scales. According to this idea in this study it was aimed that the revised the physical education self-efficacy scale which was developed by Yildirım (2012a).

\section{Method}

\section{Population and sample selection}

In the sudy it was aimed that revised the physical education teachers' self efficacy scale. According to the aim of this study it was consisted of the study group by simple random sampling. The population of the study was consisted of 576 physical education teachers (173 female physical education teachers and 394 male physical education teachers) who worked at the primary schools and high schools in different geographic regions of Turkiye. The average age of physical education teachers was $34.82 \pm 6.637$ (their ages varied between 22 and 59 years) in this research.

\section{Data collection method}

As the data collection method, the self-efficacy scale designed by Y1ldirım (2012a; 2012b; 2013) with 36 items was used. Besides, a draft scale with 41 items, which was prepared by adding 5 
Yıldırım İ. (2015). Revised version of physical education teachers' self-efficacy scale. International Journal of Human Sciences, 12(1), 870-886. doi: $10.14687 /$ ijhs.v12i1.3100

extra items to the original scale after a literature review, was employed in addition to general teacher competence guidelines established by National Education Ministry (http://otmg.meb.gov.tr), academic competence guidelines for physical education teachers and self-efficacy scale for physical education teachers designed by Ünlü et al. (2008). The scale items had a 5-point Likert format with close-ended questions and the coding was on 9 point rating system as follows: 1. Never, 3. Slightly, 5: Somewhat, 7. Good and 9. Very good.

\section{Analyzes of data}

Adequacy of the data collected for the factor analysis was examined using Bartlett's Test of Sphericity while adequacy of the size of the study-sample was examined using Keiser-MeyerOlkin coefficient. Subscales were established using explanatory factor analysis. In the explanatory factor analysis conducted to determine the scale items; it was paid attention to that eigenvalue of items should not be smaller than 1, factor loading values of items should be at least .50, items should be clustered under one factor and the difference in loading values of the items between two or more factors should not be smaller than 1 (Çokluk et al., 2010; Alpar, 2010). In the explanatory analysis; 25 degree varimax axis rotation test and principal components analysis were employed. After the explanatory factor analysis, confirmatory factor analysis was used through Lisrel package software. First, first-level and then second-level confirmatory analyses were conducted. Cronbach Alpha internal consistency tests was administered for the subscales found as the result of explanatory and confirmatory factor analyses and for the total scale in order to determine internal consistency of the scale.

\section{Results}

According to the results of KMO and Bartlett's Test of Sphericity seen in Table 1; it was accepted that it was adequate to administer factor analysis for the relevant data group.

Table 1. KMO and Bartlett's Test: Physical education teachers self-efficacy scale

\begin{tabular}{lll}
\hline \multicolumn{2}{l}{ Kaiser-Meyer-Olkin Measure of Sampling Adequacy. } & 0.923 \\
\hline & Approx. Chi-square & 14144.995 \\
\cline { 2 - 3 } Bartlett's Test of Sphericity & $\mathrm{df}$ & 528 \\
\cline { 2 - 3 } & Sigificance (p) & 0.001 \\
\hline
\end{tabular}

When slope graphs were analyzed in Figure 1, it was seen that there was a break after the $9^{\text {th }}$ point. 
Yıldırım İ. (2015). Revised version of physical education teachers' self-efficacy scale. International Journal of Human Sciences, 12(1), 870-886. doi: $10.14687 /$ ijhs.v12i1.3100

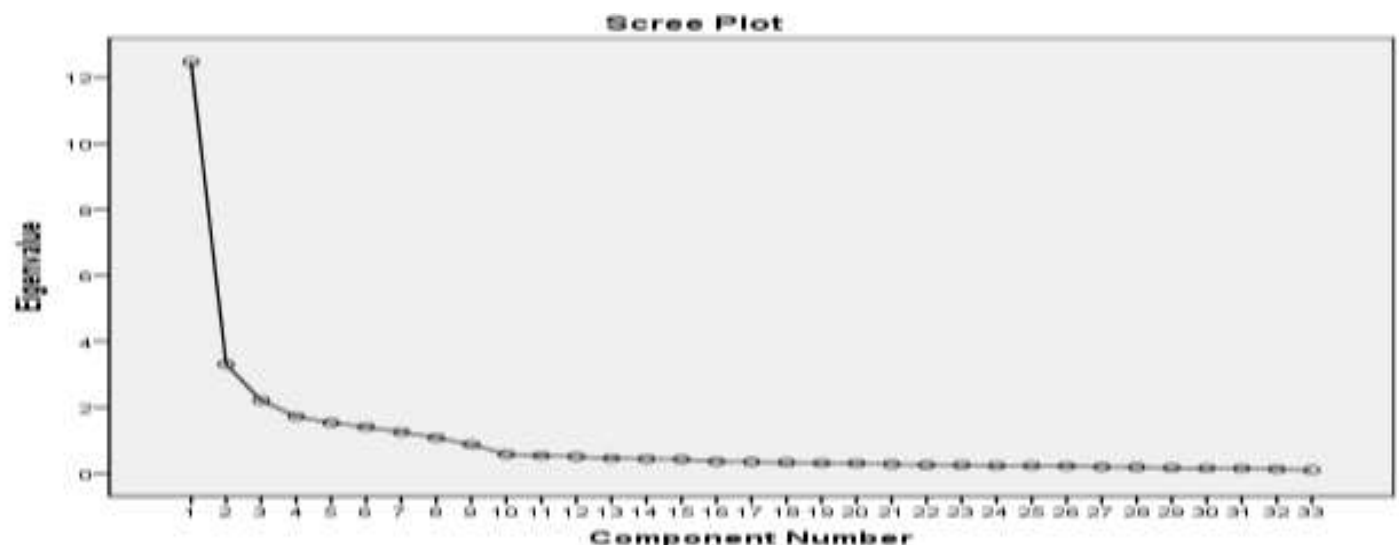

Fig.1. Scree plot graphic.

Table 2. Rotated Component Matrix: Physical education teachers self-efficacy scale

\begin{tabular}{|c|c|c|c|c|c|c|c|c|c|}
\hline & & & & & onent & & & & \\
\hline & 1 & 2 & 3 & 4 & 5 & 6 & 7 & 8 & 9 \\
\hline Self-efficacy 03 & .908 & & & & & & & & \\
\hline Self-efficacy 02 & .903 & & & & & & & & \\
\hline Self-efficacy 01 & .880 & & & & & & & & \\
\hline Self-efficacy 04 & .875 & & & & & & & & \\
\hline Self-efficacy 05 & .786 & & & & & & & & \\
\hline Self-efficacy 24 & & .844 & & & & & & & \\
\hline Self-efficacy 23 & & .833 & & & & & & & \\
\hline Self-efficacy 22 & & .776 & & & & & & & \\
\hline Self-efficacy 25 & & .706 & & & & & & & \\
\hline Self-efficacy 27 & & & .846 & & & & & & \\
\hline Self-efficacy 28 & & & .803 & & & & & & \\
\hline Self-efficacy 26 & & & .793 & & & & & & \\
\hline Self-efficacy 29 & & & .710 & & & & & & \\
\hline Self-efficacy 32 & & & & .786 & & & & & \\
\hline Self-efficacy 31 & & & & .748 & & & & & \\
\hline Self-efficacy 30 & & & & .665 & & & & & \\
\hline Self-efficacy 33 & & & & .654 & & & & & \\
\hline Self-efficacy 36 & & & & & .849 & & & & \\
\hline Self-efficacy 35 & & & & & .842 & & & & \\
\hline Self-efficacy 34 & & & & & .796 & & & & \\
\hline Self-efficacy 19 & & & & & & .812 & & & \\
\hline Self-efficacy 18 & & & & & & .794 & & & \\
\hline Self-efficacy 20 & & & & & & .738 & & & \\
\hline Self-efficacy 17 & & & & & & & .782 & & \\
\hline Self-efficacy 16 & & & & & & & .714 & & \\
\hline Self-efficacy 14 & & & & & & & .671 & & \\
\hline Self-efficacy 13 & & & & & & & .577 & & \\
\hline Self-efficacy 07 & & & & & & & & .825 & \\
\hline Self-efficacy 08 & & & & & & & & .813 & \\
\hline Self-efficacy 09 & & & & & & & & .767 & \\
\hline Self-efficacy 39 & & & & & & & & & .800 \\
\hline Self-efficacy 40 & & & & & & & & & .767 \\
\hline Self-efficacy 38 & & & & & & & & & .761 \\
\hline
\end{tabular}

It was seen in Table 2 that 33 items whose factor loading values were over 0.577 were clustered under nine factors. 
Yıldırım İ. (2015). Revised version of physical education teachers' self-efficacy scale. International Journal of Human Sciences, 12(1), 870-886. doi: $10.14687 /$ ijhs.v12i1.3100

Table 3. Total Variance Explained and Cronbach's Alpfa $(\alpha)$

\begin{tabular}{lccc}
\hline \multirow{2}{*}{ Factors } & Eigen & Explained & Cronbach's \\
& Value & Variance $(\%)$ & Alpha $(\alpha)$ \\
\hline Self-efficacy in the usage of technology & 4.246 & 12.867 & 0.942 \\
Self-efficacy in special field knowledge & 3.188 & 9.662 & 0.902 \\
Self-efficacy in finding resource and providing support, & 3.036 & 9.200 & 0.865 \\
Self-efficacy in planning, & 2.770 & 8.394 & 0.886 \\
Self-efficacy in special education & 2.634 & 7.980 & 0.900 \\
Self-efficacy in verbal and non-verbal communication, & 2.577 & 7.808 & 0.878 \\
Self-efficacy in classroom management & 2.570 & 7.789 & 0.839 \\
Self-efficacy in assessment and evaluation & 2.425 & 7.349 & 0.888 \\
Self-efficacy in improving physical performance. & 2.413 & 7.312 & 0.876 \\
\hline Self-efficacy scale (Total) & & 78.362 & 0.944 \\
\hline
\end{tabular}

When Table 3 was examined, it was seen that accountability of the self-efficacy scale clustered into 9 subscales was 78.362. When internal consistency test of the self-efficacy scale was examined, general Cronbach's Alpha value was found to be 0.944 .

First-level confirmatory analysis was conducted after explanatory factor analyses.

Table 4. Fit criteria and the results of First-level confirmatory analysis of the self-efficacy scale

\begin{tabular}{llll}
\hline Fit Measure & Good Fit & Acceptable Fit & Model Fit Data \\
\hline $\mathrm{X}^{2} / \mathrm{df}$ & $0 \leq \mathrm{X}^{2} / \mathrm{df} \leq 2$ & $2 \leq \mathrm{X}^{2} / \mathrm{df} \leq 3$ & 2.808 \\
\hline RMSEA & $0 \leq \mathrm{RMSEA} \leq 0.05$ & $0.05<\mathrm{RMSEA} \leq 0.10$ & 0.057 \\
\hline SRMR & $0 \leq \mathrm{SRMR} \leq 0.05$ & $0.05<\mathrm{SRMR} \leq 0.10$ & 0.040 \\
\hline NFI & $0.95 \leq \mathrm{NFI} \leq 1.00$ & $0.90 \leq \mathrm{NFI} \leq 0.95$ & 0.97 \\
\hline NNFI & $0.97 \leq \mathrm{NNFI} \leq 1.00$ & $0.95 \leq \mathrm{NNFI} \leq 0.97$ & 0.98 \\
\hline CFI & $0.97 \leq \mathrm{CFI} \leq 1.00$ & $0.95 \leq \mathrm{CFI} \leq 0.97$ & 0.98 \\
\hline
\end{tabular}

There are various fit indexes to test the adequacy of the model constructed by the confirmatory factor analysis. The proportion of chi-square of the model to degrees of freedom was found out by RMSEA (Root-mean square error approximation), SRMR (Standardized Root Mean Square Residual), NFI (Normed Fit Index), NNFI (Nonnormed Fit Index) and CFI (Comparative Fit Index) (Schermelleh et al.,2003; Çelik, 2009; Yılmaz and Çelik, 2009).

When Table 4 was studied, it was seen that fit criteria were within acceptable fit limits and good fit limits (Schermelleh et al.,2003;Çelik, 2009; Yılmaz and Çelik, 2009). When Figure 2 and Table 4 was studied, it was seen as a result of first-level confirmatory analysis that $\mathrm{X}^{2} / \mathrm{df}$ value, RMSEA and SRMR values were within acceptable fit limits while NFI, NFFI and CFI values were within good fit limits. According to these values, it may be argued that the model constructed was a suitable model as far as the data used were concerned. Also, when Path Diagram of the first-level confirmatory factor analysis of the self-efficacy scale was examined, it was established that all of 
Yıldırım İ. (2015). Revised version of physical education teachers' self-efficacy scale. International Journal of Human Sciences, 12(1), 870-886. doi: $\underline{10.14687 / \text { ijhs.v12i1.3100 }}$

the subscales were in positive correlation with each other and each of the subscales and their explanatory items were in positive correlation $(p<0.05)$. Therefore, the second-level confirmatory factor analysis was initiated.

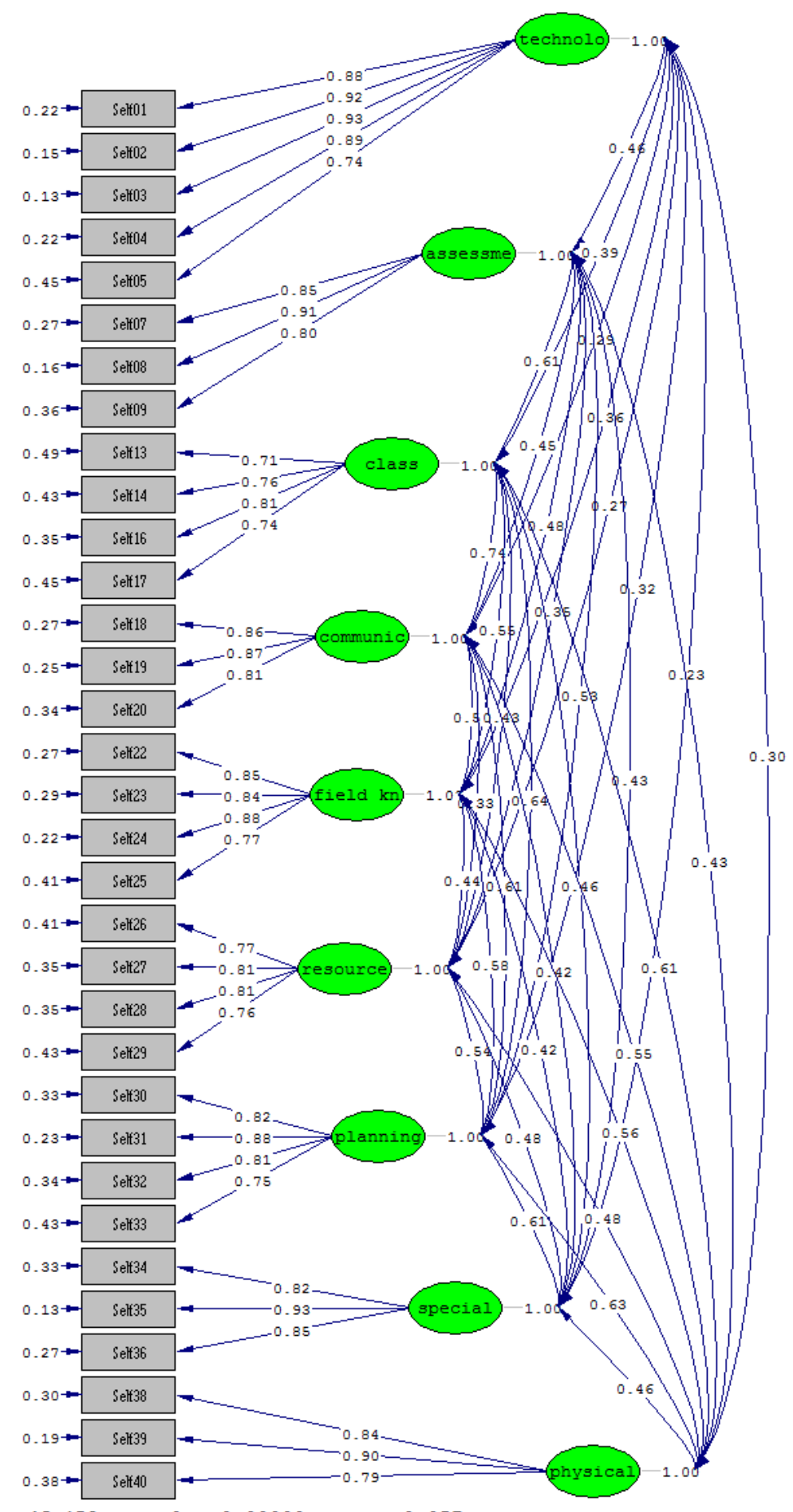

Chi-Square $=1289.08, d f=459, \mathrm{P}-\mathrm{value}=0.00000, \mathrm{RMSEA}=0.057$

Figure 2. Path Diagram of first-level confirmatory factor analysis of self-efficacy scale (Technolo: Self-efficacy in the usage of technology; Assesme: Self-efficacy in assessment and evaluation; Class: Self-efficacy in classroom management; Communic: Self-efficacy in verbal and non-verbal communication; Field kn: self-efficacy in special field knowledge; Resource: Self-efficacy in finding resource and providing support; Planning: Self-efficacy in planning; Special: Self-efficacy in special education; Physical: Self-efficacy in improving physical performance). 
Yıldırım İ. (2015). Revised version of physical education teachers' self-efficacy scale. International Journal of Human Sciences, 12(1), 870-886. doi: $10.14687 /$ ijhs.v12i1.3100

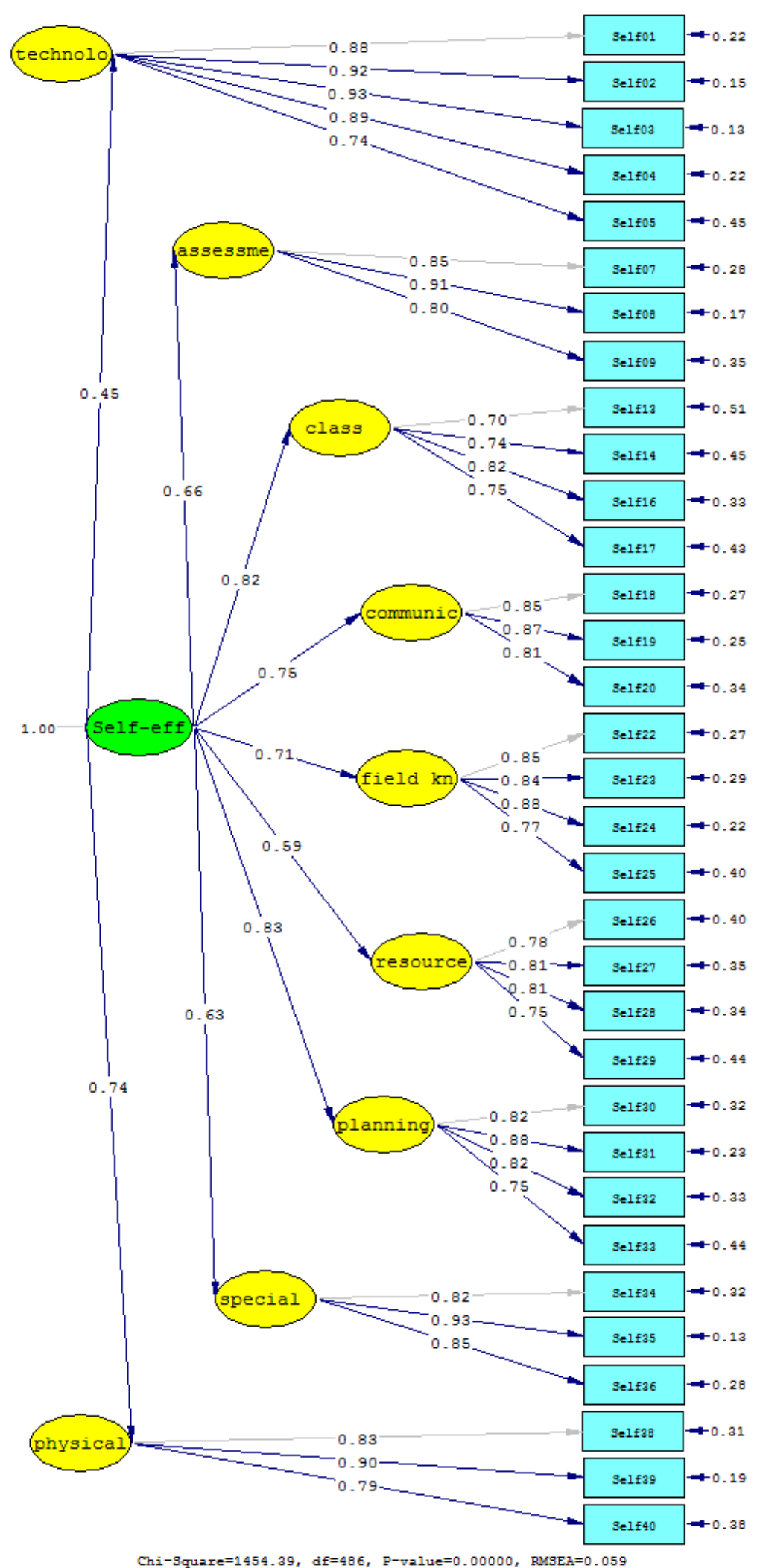

Figure 3. Path Diagram of second-level confirmatory factor analysis of self-efficacy scale 
Yildırım İ. (2015). Revised version of physical education teachers' self-efficacy scale. International Journal of Human Sciences, 12(1), 870-886. doi: $10.14687 /$ ijhs.v12i1.3100

Table 5. Fit criteria and the Results of second-level confirmatory factor analysis of self-efficacy scale

\begin{tabular}{llll}
\hline Fit Measure & Good Fit & Acceptable Fit & Model Fit Data \\
\hline $\mathrm{X}^{2} / \mathrm{df}$ & $0 \leq \mathrm{X}^{2} / \mathrm{df} \leq 2$ & $2 \leq \mathrm{X}^{2} / \mathrm{df} \leq 3$ & 2.992 \\
\hline RMSEA & $0 \leq \mathrm{RMSEA} \leq 0.05$ & $0.05<\mathrm{RMSEA} \leq 0.10$ & 0.059 \\
\hline SRMR & $0 \leq \mathrm{SRMR} \leq 0.05$ & $0.05<\mathrm{SRMR} \leq 0.10$ & 0.054 \\
\hline NFI & $0.95 \leq \mathrm{NFI} \leq 1.00$ & $0.90 \leq \mathrm{NFI} \leq 0.95$ & 0.97 \\
\hline NNFI & $0.97 \leq \mathrm{NNFI} \leq 1.00$ & $0.95 \leq \mathrm{NNFI} \leq 0.97$ & 0.98 \\
\hline CFI & $0.97 \leq \mathrm{CFI} \leq 1.00$ & $0.95 \leq \mathrm{CFI} \leq 0.97$ & 0.98 \\
\hline
\end{tabular}

When Table 5 was examined, it was seen that fit criteria were within acceptable fit limits and good fit limits (Schermelleh et al.,2003;Çelik, 2009; Yılmaz and Çelik, 2009). When Figure 2 and Table 5 were studied, it was seen as the result of second-level CFA that $\mathrm{X}^{2} / \mathrm{df}$ values, RMSEA and SRMR values were within acceptable fit limits while NFI, NFFI and CFI values were within good fit limits. According to these values, it may be argued that the model constructed was a suitable model as far as the data used were concerned.

Also, when Path Diagram of the second-level confirmatory factor analysis of the self-efficacy scale was examined, it was established that all of the subscales were in positive correlation with each other and each of the subscales and their explanatory items were in positive correlation $(\mathrm{p}<0.05)$. When the correlation between self-efficacy scale and its subscales was analyzed, the highest correlation was found to be between "self-efficacy in classroom management and selfefficacy in planning" subscales and total of self-efficacy scale.

\section{Discussion}

In the study which was conducted to develop a scale of self-efficacy for physical education teachers, construct validity of the scale was established using explanatory factor analysis and confirmatory factor analysis.

For social sciences; factor analyses are made in order to establish construct validity in scale development studies and scale adaptation studies. Factor analysis is a statistical method with multi-variables used to describe variability among observed, correlated variables in terms of a potentially lower number of unobserved variables called factors and to investigate whether a number of variables of interest are related to a smaller number of unobservable factors (Çokluk et al., 2010; Büyüköztürk, 2011). There are two factor analyses: Explanatory Factor Analysis and Confirmatory Factor Analysis. Explanatory Factor Analysis (EFA) does not only reduce the number of the variables and identifies the underlying relationships among the variables but also serves to identify latent constructs underlying a behavior. In other words, it is a kind of 
Yıldırım İ. (2015). Revised version of physical education teachers' self-efficacy scale. International Journal of Human Sciences, 12(1), 870-886. doi: $10.14687 /$ ijhs.v12i1.3100

explanatory analysis employed to question whether or not certain items clustered under a factor are indicators of the theoretical construct.

Confirmatory Factor Analysis (CFA) is used to test whether the observed data of a model are consistent and fit with the measurement model identifying the underlying variables and presents detailed statistics regarding to what extent these data fit with the model. In the construct validity tests, it is a common and accepted method to employ confirmatory factor analysis after explanatory factor analysis (Çokluk et al., 2010; Worthington and Whittaker, 2006).

Before explanatory factor analysis, Kaiser-Meyer-Olkin (KMO) test was administered in order to test whether or not sample-size was suitable for factorialization. When the literature is examined, KMO values between 0.50 and 0.60 are considered bad, between 0.60 and 0.70 weak, between 0.70 and 0.80 moderate, between 0.80 and 0.90 good and over 0.90 excellent. It is emphasized that factor analyses cannot be performed if $\mathrm{KMO}$ is smaller than 0.50. It is accepted that the nearer $\mathrm{KMO}$ value gets to 1 , the more suitable it is to administer the factor analyses. However, if the KMO value is smaller than 0.5 factor analyses cannot be proceeded because the correlation between variable-pairs cannot be explained by other variables (Bayram, 2004; Alpar, 2010; Çokluk et al., 2010). In this study, it was found out that KMO value of the self-efficacy scale for the physical education teachers was 0.923 (Table 1); by which it was concluded that sample size was "excellent" to perform factor analyses. Besides, when Bartlett's Test of Sphericity was studied, the Chi-square value obtained was seen to be significant ( $\mathrm{x}^{2}$ (528):14144.995; $\left.\mathrm{p}<0.001\right)$. Therefore, it was accepted that the data followed a normal distribution with multi-variables. As the result of the findings of KMO and Bartlett's Test of Sphericity, the relevant data group was considered suitable for factor analysis and explanatory factor analysis was initiated.

Varimax orthogonal axis rotation test and principal components analysis were employed as factorialization method in order to explore the factor construct of the self-efficacy scale for the physical education teachers. The first phase of the explanatory analysis was made with 41 items. As the result of the first-level explanatory analysis; $6^{\text {th }}, 10^{\text {th }}, 11^{\text {th }}, \quad 12^{\text {th }}, 37^{\text {th }}$ and $41^{\text {st }}$ items were removed from the scale because their factor loadings were smaller than 0.50 and they appeared in more than one subscales and there was adjacency of these items. The second phase of explanatory analysis was made with 33 items. As the result of the repeated EFA Varimax orthogonal axis rotation test, it was found out that the smallest factor loading value was 0.577 (Table 2). Factor values are standardized regression coefficients and indicate the correlation between variable and factor. Smaller factor loading demonstrate that the item is not strongly correlated with that factor. Although it is stated in literature that minimum factor loading value 
Yıldırım İ. (2015). Revised version of physical education teachers' self-efficacy scale. International Journal of Human Sciences, 12(1), 870-886. doi: $10.14687 /$ ijhs.v12i1.3100

should be 0.30 , there are also other theoreticians that argue that minimum factor loading value should be $\geq 0.40$. In general, loading values between 0.30 and 0.59 are identified as moderate while those $\geq 60$ as high (Çokluk et al., 2010). In line with that information in literature, it was established that factor loading values of the items that made up self-efficacy scale for the physical education teachers were high and very good.

As the result of the EFA conducted with 33 items; when slope graphs were analyzed in Figure 1, it was seen that there was a break after the $9^{\text {th }}$ point and there were 9 subscales whose eigenvalues were greater than 1 (Figure 1 and Table 3). The eigenvalue of an item reflects the power of the correlation between the factor and original variables. Eigenvalues are used to estimate variances identified by factors and to decide the number of the factors. In the factor analyses, those factors whose eigenvalues are $\geq 1$ are accepted as stable (Alpar, 2010; Çokluk et al., 2010). As the result of the factor analysis made, it was decided that self-efficacy scale for the physical education teachers would have 9 factors because there were 9 components whose eigenvalues were $\geq 1$ and there was a break after the $9^{\text {th }}$ point in the slope graphs. Therefore; the subscales were termed as follows: Self-efficacy in the usage of technology, Self-Efficacy in classroom management, Selfefficacy in special field knowledge, Self-Efficacy in finding resource and providing support, SelfEfficacy in verbal and non-verbal communication, Self-Efficacy in planning, Self-efficacy in special education, Self-Efficacy in assessment and evaluation and Self-Efficacy in improving physical performance. As the result of the analysis, it was discovered that factor loadings of the items which were clustered under 9 subscales were over 0.57 and the percentage of variance explained by the nine factors was 78.362. The size of the variance explained indicates the strength of the factor construct of the scale. In the practice; with multifactorial models, it is enough for a variance to be between $40 \%$ and $60 \%$ in scale developing in social sciences and there are some examples in the studies (Alpar, 2010; Çokluk et al., 2010; Ünlü, 2012). In this sense, it was concluded that the percentage of variance found for the self-efficacy scale for the physical education teachers was considerably high and acceptable.

After conducting explanatory factor analysis, we proceeded to confirmatory factor analysis. It is kind of analysis through which a pre-identified and predetermined construct is tested to decide whether it is confirmed as a suitable model or not. Besides, this analysis is used to confirm "theoretical structure" or "theoretical model", too. Whether or not self-efficacy scale for the physical education teachers could be confirmed was tested using first-level confirmatory factor analysis and second-level confirmatory factor analysis. Fit indexes are used to determine the adequacy of the model constructed in confirmatory factor analysis (Table 4). These indexes are 
Yildırım İ. (2015). Revised version of physical education teachers' self-efficacy scale. International Journal of Human Sciences, 12(1), 870-886. doi: $10.14687 /$ ijhs.v12i1.3100

the proportion of chi-square of the model to degrees of freedom, RMSEA, SRMR, NFI, NNFI and CFI (Schermelleh et al., 2003; Çokluk et al., 2010).

As the result of the first-level Confirmatory Factor Analysis of the self-efficacy scale for the physical education teachers; it was seen that $\mathrm{X}^{2} / \mathrm{df}$ value $(1289.08 / 459=2.808)$, RMSEA $(0.057)$ and SRMR (0.040) values were within acceptable fit limits while NFI (0.97), NFFI (0.98) and CFI (0.98) values were within good fit limits (Table 4). Therefore, no modification was needed among the items because the first-level Confirmatory Factor Analysis of the self-efficacy scale for the physical education teachers turned out to have good fit. Meydan and Şeşen (2011) underlined that second-level multifactorial models of the multi-dimensional scales should be tested while performing confirmatory factor analysis. Therefore; our model with nine dimensions were tested using the second-level CFA results.

As the result of the second-level CFA of the self-efficacy scale for the physical education teachers; it was seen that it was seen that $\mathrm{X}^{2} / \mathrm{df}$ value (1454.39/486=2.992), RMSEA (0.059) and SRMR (0.054) values were within acceptable fit limits while NFI (0.97), NFFI (0.98) and CFI (0.98) values were within good fit limits (Table 5). No modification was needed among the items because the second-level CFA of the self-efficacy scale for the physical education teachers turned out to have good fit. In conclusion, it may be proposed that the model constructed was a suitable model as far as the data used were concerned.

Internal consistency tests were separately administered for the subscales and the total scale produced in light of the Explanatory and Confirmatory Factor analyses and their Cronbach's Alpha values were estimated. Cronbach's Alpha coefficients are a criterion for internal consistency (homogeneity) of the items of the scale. It is accepted that the higher Cronbach's Alpha coefficients are, "the more consistent the items of the scale are with each other and the more closely they inquiry the parts of the same characteristics"; which points out that the items work together in coordination. Cronbach's alpha coefficients between 0.00 and 0.039 mean that the test is not reliable, 0.40 and 0.59 low reliable, 0.60 and 0.70 very reliable and 0.80 and 1.00 highly reliable (Alpar, 2010). In the current study, the highest Cronbach's alpha coefficient (0.942) was obtained for Self-Efficacy in Using Technology whereas the lowest Cronbach's alpha coefficient (0.839) for Self-Efficacy in classroom management. General Cronbach's alpha coefficient for the total scale was 0.944; which demonstrated that the self-efficacy scale for the physical education teachers was highly reliable.

Although the current scale which was developed as the result of the analyses performed was similar to the scale developed and used in some studies by Yildırım (2012a, 2012b, 2013); there 
Yıldırım İ. (2015). Revised version of physical education teachers' self-efficacy scale. International Journal of Human Sciences, 12(1), 870-886. doi: $10.14687 /$ ijhs.v12i1.3100

were significant differences between the two scales. In the first study of Ylldirım (2012a), construct validity of the self-efficacy scale was performed using explanatory factory analysis and it was seen as the result of the analysis that the percentage of variance explained for the scale with 36 items and eight factors whose eigenvalues were bigger than 1 was 75.091 for total variance and internal consistency test presented Cronbach's Alpha value as 0.950. In another study conducted by Yildırm (2012b, 2013) to determine construct validity using explanatory and first-level confirmatory factor analyses; it was found out that the scale was consisted of 32 items and eight factors whose Eigen values were bigger than 1 .

The percentage of variance explained was 74.747 for total variance. In internal consistency test, Cronbach's Alpha value of the scale was found to be 0.950 . As for our study; the percentage of variance explained for the scale with 33 items and nine factors whose Eigen values were bigger than 1 was 78.362 for total variance. In internal consistency test, Cronbach's Alpha value of the scale was found to be 0.942 . In the current self-efficacy scale, there were three new items and these items were clustered under one factor which was termed as "Self-Efficacy in improving physical performance". Besides; it was noted that percentage of variance explained for the scale was higher than other scales. Confirming the self-efficacy scale for the physical education teachers through first-level confirmatory factor analysis and second-level factor analysis after the explanatory factor analysis, exploring a high percentage for the total variance and high Cronbach's Alpha values will increase the importance of the scale and will indicate that the scale has a "valid, reliable and strong theoretical basis".

\section{Conclusions and recommendations}

The self-efficacy scale for the physical teachers is a measurement tool with 33 items which was clustered into 9 subscales and developed to measure professional self-efficacy of teachers. The subscale of Self-efficacy in the usage of technology is consisted of 5 items and measures teachers' belief that they can utilize technology in education by following technological advancements. The subscale of Self-efficacy in special field knowledge is consisted of 4 items and measures teachers' belief about professional knowledge and skills about physical education and sports. The subscale of Self-efficacy in finding resource and providing support is consisted of 4 items and measures teachers' belief that they can find resources and provide support by using private sector, public sector and other external factors for the needs such as fields, sportive materials and etc. The subscale of Self-efficacy in planning is consisted of 4 items and measures teachers' belief that they can rationally design teaching activities in order to attain and to realize program objectives in 
Yıldırım İ. (2015). Revised version of physical education teachers' self-efficacy scale. International Journal of Human Sciences, 12(1), 870-886. doi: $10.14687 /$ ijhs.v12i1.3100

teaching programs. The subscale of Self-efficacy in special education is consisted of 3 items and measures teachers' belief that they can meet the needs of those students whose educational abilities and individual characteristics are different from the level that should be expected. The subscale of Self-efficacy in verbal and non-verbal communication is consisted of 3 items and measures teachers' belief that they can develop effective communication through (effective) speaking, rhetoric, tone, looks, gestures, body movements, body signs and mimics. The subscale of Self-efficacy in classroom management is consisted of 4 items and measures teachers' belief that they can prepare and maintain the best classroom environment and conditions for an effective learning and teaching. The subscale of Self-efficacy in assessment and evaluation is consisted of 3 items and measures teachers' belief that they can attain a standard of judgment about the subject measured by observing students' different qualifications, expressing numerical data and symbols and comparing the final results to criteria. The subscale of the development of physical performance is consisted of 3 items and measures teachers' belief that they can improve the students through sportive activities in line with their interests and abilities.

As a result; it is predicted that the scale can be used in a valid and reliable way in order to measure self-efficacy of the physical education teachers.

\section{References}

Akkoyunlu, B., Orhan, F. \& Umay, A. (2005). A Study on Developing Self-Efficacy Scale for IT Teacher. Hacettepe University Education Faculty Journal (H. U. Journal of Education) 29: 1-8.

Alpar, R. (2010). Spor, Sağlle ve Eğitim Bilimlerinden Örneklerle Uygulamal Istatistik ve GeçerlikGüvenirlik. [Applied Statistics and Validity-Reliability Studies with Examples from Sports, Health and Education]. I. Bask1; Detay Yayınc1lk, s. 141,313-395.

Atıc1, M. (2000). An exploration of the relationships between classroom management strategies and teacher efficacy in English and Turkish primary school teachers. PhD Thesis, Leicester University, England.

Bandura, A. (1977). Self-efficacy: Toward A Unifying Theory of Behavioral Change, Psychological Review. 84(2): 191-215.

Bandura, A. (1986). Social Foundation of Thought and Action: A Social Cognitive Theory. Englewood Cliffs, NJ: Prentice-Hall.

Bandura, A. (1994). Self-efficacy, In V.S. Ramachaudran(Ed.), Encyclopedia of Human Behavior. Newyork: Academic Press. (4): 71-81.

Bandura, A. (1997). Self-efficacy: The Exercise of Control, W. H. Freeman and Company, New York.

Bayram, N. (2004). Sosyal Bilimlerde SPSS ile Veri Analizi [Data analysis with SPSS in social sciences]. I. Bask1, Bursa, Ezgi Kitabevi.

B1kmaz, F.H. (2002). Scale of Self-efficacy Belief for Science Teaching. Education Sciences and Practice,1(2):197-210. 
Yıldırım İ. (2015). Revised version of physical education teachers' self-efficacy scale. International Journal of Human Sciences, 12(1), 870-886. doi: $10.14687 /$ ijhs.v12i1.3100

Bozgeyikli, H. (2005). The Effect of Professional Group Guidance on the level of feeling competent to decide jobs by $8^{t h}$ grade students. PhD Thesis, Selçuk University, Social Sciences Institute, Konya,1012.

Büyüköztürk, Ş. (2011). Sosyal Bilimler İ̧in Veri Analiæ̧i El Kitabı [Data Analysis Handbook for Social Sciences]. 14. Bask1, Ankara, Pegem Akademi Yayın, s.123-125.

Çelik, H.E. (2009). Modeling structured equity and its application: Extended online shopping acceptance model. Eskişehir Osmangazi University Natural Sciences Institute, Eskişehir, PhD Thesis, 140155.

Çokluk, Ö., Şekercioğlu, G. \& Büyüköztürk, Ş. (2010). Sosyal Bilimler İçin Çok Değişkenli İstatistik SPSS ve Lisrel Uygulamalar1 [Multi-variable statistical SPSS and Lisrel Practices for Social Sciences]. Pegem Akademi Yayınevi, s.177, 190-246.

Ekici, G. (2005). Validity and Reliability Tests of self-efficacy scale for Biology. Hacettepe University Education Faculty Journal, 29: 85-94.

Enochs, L.G. \& Riggs, I.M. (1990). Further development of an elementary science teaching efficacy belief instrument: A preservice elementary scale. School Science and Mathematics. 90(8): 694-706.

Gokyer, N. (2012). Primary school teachers' perceptions of teacher competencies realisation levels. Energy Educ Sci Technol Part B, 4(2):843-856.

Gökçe, E. (2000). Teacher of the $21^{\text {st }}$ Century. Cağdaş Education Journal. 270: 21-26.

Guskey, T.R. \& Passaro, P.D. (1994). Teacher efficacy: A study of construct dimensions. American Educational Research Joumal, 31: 627-643.

Gürcan, A. (2005). The correlation between IT self-efficacy perception and cognitive learning strategies. Eurasian Journal of Educational Research.19:179-193.

http://otmg.meb.gov.tr/belgeler/ogretmen yeterlikleri kitabi/Öğretmen Yeterlikleri_Kitab1 be den eğitimi öğretmeni özel alan yeterlikleri ilköğretim parça 14.pdf. 26.05.2013.

Kiremit, H.Ö. (2006). Comparison of biology self-efficacy beliefs among the students of Science Teaching. Dokuz Eylül University Social Sciences Institute, İzmir, Ph.D.Thesis, 30-50.

Koparan, S.., Öztürk, F. \& Korkmaz, N.H. (2011). Examination of Self-efficacy and physical education efficacy of Physical Education Teachers. National Physical Education and Sports Teaching Congress, V an, YY University Education Faculty Journal Special Issue. 52-61.

Meydan, C.H. \& Şeşen, H. (2011). Yapısal Essitlike Modellemesi AMOS Uygulamalar [Modeling structured equity AMOS Practices]. Ankara: Detay yayınevi.

Pajares, F. (1997). Current Directions in Self Efficacy Research. Greenwich, CT: JAI Pres. In M. Maehr\&P.R. Pintrich (Eds.) Advances in Motivation and Achievement,10:1-49.

Riggs, I.M. \& Enochs, L.G. (1990). Toward the development of an elementary teacher's science teaching efficacy belief instrument. Science Education, 74(6):625-637.

Savran, A. \& Çakıroğlu, J. (2003). Differences between Elementary and Secondary Preservice Science Teacher's Perceived Efficacy Beliefs and Their Classroom Management Beliefs. $3^{\text {rd }}$ International Education Technologies Symposium, 28-30 May, Doğu Akdeniz University, Cyprus.

Schermelleh, E.K., Moosbrugger, H. \& Müller, H. (2003). Evaluating the fit of Structural Equation Models: Test of Significance and Descriptive Goodness-of-fit Measures. Methods of Psychological Research - Online, 8(2): 23-74. 
Yıldırım İ. (2015). Revised version of physical education teachers' self-efficacy scale. International Journal of Human Sciences, 12(1), 870-886. doi: $10.14687 /$ ijhs.v12i1.3100

Schmitz, G.S. \& Schwarzer, R. (2000). Selbstwirksamkeitserwartung von Lehrern: Längsschnittbefunde mit einem neuen Instrument. Zeitschrift für Padagogische Psychologie,14 (1):12-25.

Schunk, D.H. \& Pajares, F. (2001). The Development of Academic Self-efficacy, (ed.) Development of Achivement Motivation, 1-27, Academic Press, San Diego.

Tschanen-Moran, M.\& Woolfolk, A.H. (1998). Teacher efficacy: Its meaning and measure. Review of Educational Research. 68: 202-248.

Tschannen-Moran, M. \& Woolfolk, A.H. (2001). Teacher efficacy: Capturing an elusive concept. Teaching and Teacher Education, 17: 783-805.

Ünlü, H. (2012). Collective efficacy of physical education teachers. Energy Educ Sci Technol Part B, 4(2):1053-1060.

Ünlü, H., Sünbül, M. \& Aydos, L. (2008). Validity and Reliability Tests of Self-Efficacy Scale for Physical Education Teachers. Kirşehir Education Faculty Journal, 9 (2):23-33.

Worthington, R.W. \& Whittaker, T.A. (2006). Using exploratory and confirmatory factor analysis in scale development research: A content analysis and recommendations for best practices. The Counseling Psychologist. 34(6): 806-838.

Yildırım, İ. (2012a). Developing a scale for self-efficacy of physical education teachers. Energy Educ Sci Technol Part B, 4(3):1491-1500.

Yıldırım, İ. (2012b). An Analysis of Organizational Citizenship Bebaviors and Self-efficacy of Physical Education Teachers. Ondokuz May1s University Health Sciences Institute, Samsun, PhD Thesis, 38-42.

Yıldırım, İ., Kabadayı, M., Taşmektepligil, M.Y. et al. (2013) Validity and Reliability Tests of SelfEfficacy Scale for Physical Education Teachers. International Balkan Symposium in Sport Sciences, Book Of Abstracts, 40-42.

Yilmaz, G., Yilmaz, B. \& Türk, N. (2010). Examination of Self-efficacy level of Physical Education Teachers about their professions (Nevşehir Province Sample). Selçu University Physical Education and Sports Journal. 12 (2):85-90.

Yılmaz, V. \& Çelik, H.E. (2009). Lisrel ile Yapısal Eşitlik Modellemesi [Modeling structural equity with LISREL]. 1. Bask1, Ankara, Pegem Akademi Yayın1. 
Yıldırım İ. (2015). Revised version of physical education teachers' self-efficacy scale. International Journal of Human Sciences, 12(1), 870-886. doi: $10.14687 /$ ijhs.v12i1.3100

\section{Appendix}

\section{Öz-yeterlik Ölçeği (Self-Efficacy Scale)}

\section{$\begin{array}{lllllllll}\text { 1-Hiç } & 2 & 3 & 4 & 5 & 6 & 7 & 8 & \text { 9-Çok iyi }\end{array}$}

1- Bilgisayar ile ilgili sorunları ne ölçüde çözebilirsiniz?

2- $\quad$ Bilgisayarda her türlü yazı yazma ve sunu programlarını ne ölçüde kullanabilirsiniz?

3- Bilgisayarı etkin bir şekilde ne ölçüde kullanabilirsiniz?

4- Bilgisayar kavram ve terimlerini ne ölçüde bilirsiniz?

5- Alanınızla ilgili bilgiye erişmek için gerekli internet sitelerini ve yazılımlarını ne ölçüde kullanabilirsiniz?

7- $\quad$ Öğrencilerin bedensel gelişimlerine ilişkin ölçme sonuçlarını not ya da puana ne ölçüde dönüştürebilirsiniz?

8- Ö̆ğrencilerin etkinliklerdeki ilerleyişini, uygun olan ölçütleri kullanarak ne ölçüde değerlendirebilirsiniz?

9- Ölçme ve değerlendirme uygulamalarını beden eğitimi programındaki kazanımlara ne kadar uygun hale getirebilirsiniz?

13- Demokratik bir öğrenme ortamını ne ölçüde sağlayabilirsiniz?

14- Problemli öğrencilerin dersi engellemesini ne ölçüde önleyebilirsiniz?

16- Derse karşı ilgi ve güdünün sürekliliğini ne ölçüde sağlayabilirsiniz?

17- Çalışması zor öğrencilere ulaşabilmeyi ne ölçüde başarabilirsiniz?

18- Ses tonunuzu etkili biçimde ne ölçüde kullanabilirsiniz?

19- Sözel dili etkili biçimde ne ölçüde kullanabilirsiniz?

20- Beden dilini etkili biçimde ne ölçüde kullanabilirsiniz?

22- Gerektiğinde ne ölçüde İlk yardım müdahalesinde bulunabilirsiniz?

23- Beslenme ve egzersiz beslenmesi konusunda ne ölçüde bilgi sahibisiniz?

24- Sporcu sağlı̆̆ının korunması ve ilkyardım konusunda ne ölçüde bilgi sahibisiniz?

25- Öğrencilerin gelişim özellikleri ve bireysel farklılıkları konusunda ne ölçüde bilgi sahibisiniz?

26- Ders, okul ve sportif aktiviteler konusunda resmi kurumların işbirliğini ve desteğini ne ölçüde sağlayabilirsiniz?

27- Ders, okul ve sportif aktiviteler konusunda firmaların işbirliğini ve desteğini ne ölçüde sağlayabilirsiniz?

28- Ailelerin öğrencilere gerekli spor araç-gereçlerini temin etmelerini ne ölçüde sağlayabilirsiniz?

29- Ailelerin Beden Eğitimi derslerine önem vermelerini ne ölçüde sağlayabilirsiniz?

30- Dersi planlamada esneklik ve çeşitlilik ne ölçüde sağlayabilirsiniz?

31- Öğretim sürecini planlamada öğrencilerin gelişim düzeylerini ne ölçüde dikkate alabilirsiniz?

32- Planlamada öğrenme stillerini ne ölçüde dikkate alabilirsiniz?

33- Derslerin her bir öğrencinin seviyesine uygun olmasını ne ölçüde sağlayabilirsiniz?

34- Özel eğitime gereksinimi olan öğrencilerin yapabileceği, öz güven duyacakları ve kişisel farkındalıklarını geliştirebilecekleri etkinlikleri belirleme ve uygulatmayı ne ölçüde başarabilirsiniz?

35- Ö̈̆renme güçlüğü olan ve hazır bulunuşluğu yetersiz olan öğrencilere, bireyselleştirilmiş öğretim programlarını ne ölçüde uygulayabilirsiniz?

36- Öğretim yöntem tekniklerini ve öğretim ortamlarını özel eğitime gereksinimi olan öğrencilerin en üst düzeyde yararlanabilecekleri şekilde planlamaya ne ölçüde dikkat edebilirsiniz?

38- Öğrencilerin Beden eğitimi derslerine önem vermelerini ne ölçüde sağlayabilirsiniz?

39- Öğrencilerde spora karşı ilgi, sevgi ve merak uyandırabilmeyi ne ölçüde başarabilirsiniz?

40- Öğrencilerin ferdi ve takım sporları ile ilgili bilgi ve becerilerini ne ölçüde geliştirebilirsiniz? 